\title{
Nog niet klaar
}

\section{Verpleegkundige Francis van der Loos draait haar eerste 24-uursdienst in de palliatieve zorg, en de familiesituatie rond het sterfbed maakt een enorme indruk op haar.}

tekst Francis van der Loos illustratie Stouthandel

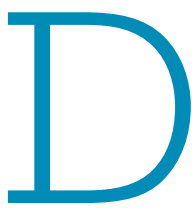

\begin{abstract}
e coördinator geeft mij een update over mevrouw $\mathrm{V}$, die net uit
\end{abstract}

het ziekenhuis is gekomen om de laatste maanden van haar leven thuis te zijn. $\mathrm{Ze}$ is in ijltempo achteruitgegaan, heeft zuurstof, een urinekatheter en een morfinepomp.

\section{Lijstjes}

Ik tref een lange, magere vrouw met opgezet gezicht en kort haar. Ze vertelt dat ze nog allerlei lijstjes wil afwerken en nog niet klaar is om dood te gaan. Mevrouw is druk en onrustig; zo is ze altijd geweest. Ze ondernam voor haar ziekte van alles tegelijk, is geliefd, heeft een groot sociaal netwerk. Haar vriend toont een foto van twee jaar geleden: een vlotte vrouw, nog volop in het leven. Mevrouw heeft drie kinderen: twee zonen en een dochter van 20 , 22 en 30 jaar. De dochter heeft een verstandelijke beperking, woont begeleid en slaapt

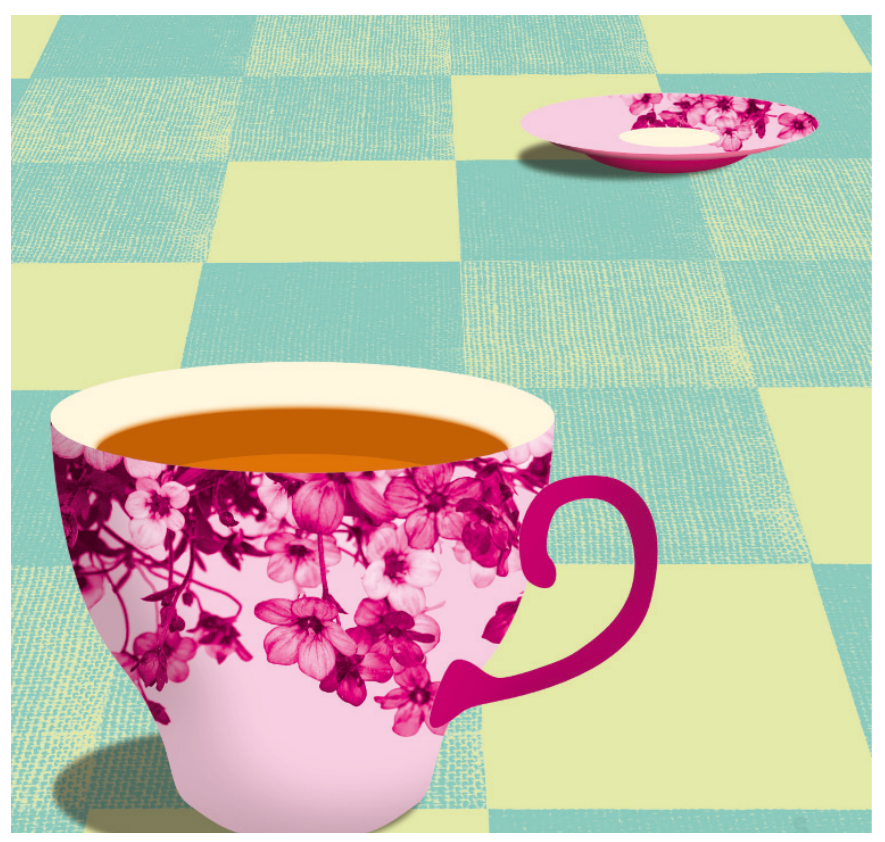

deze dagen thuis, bij moeder. Met de jongste zoon is weinig contact. De oudste zoon schakelt zijn gevoel uit en benadert alles heel verstandelijk.

\section{Niet klaar}

Mevrouw begint te hallucineren, zit soms ineens rechtop en is opstandig. Meermalen roept ze: 'Ik ga niét slapen,

\section{'Het beeld van het meisje blijft me bij: zo ver van haar moeder vandaan'}

hoor je?' Waarschijnlijk heeft ze een delier. Ze gebruikt nu een paar dagen morfine. Als de huisarts langskomt, zegt die: 'Je bent je lijden aan het verlengen. Je hebt alles geregeld: de begrafenis en de zaken rondom het huis. Je kinderen zijn hier.' Deze daadkracht en directheid lijken opluchting te geven. Mevrouw stemt in met een bewustzijnsverlagend middel. Maar in eerste instantie wordt ze alleen maar onrustiger. Ik zie hoe het is als mensen nog niet klaar zijn om te overlijden.

\section{Eng}

De dochter en de vriend van mevrouw zullen elkaar die nacht aflossen bij het waken. Om half twaalf ga ik naar bed. Kort daarop komt de dochter. Ze vindt het eng, alleen met haar moeder. 'Ze roept me en stelt vragen en dan weet ik niet wat ik moet zeggen', zegt het meisje. $\mathrm{Nu}$ is een 24-uursdienst geen waakdienst. Maar deze situatie krijgt een onverwachte wending door de angst van het meisje en de plotse achteruitgang van mevrouw. De dochter zit op de grond een paar meter bij haar moeder vandaan. Ik maak thee en ga tussen hen in zitten. Zo zitten we daar een tijdje, kletsen wat. Mevrouw roept vanuit haar bed hele verhalen. Ze zit rechtop, zwaait met haar armen. Pas als ze wat rustiger wordt, durft de dochter te gaan slapen.

Vlak nadat ik wegga, overlijdt mevrouw, zo snel kan het soms gaan. Het beeld van het meisje blijft me bij: zo ver van haar moeder vandaan. Ik besef hoe belangrijk de gemoedsrust van haar moeder voor haar was. Maar ook mijn aanwezigheid daar. Dat stemt me enorm dankbaar. 